\title{
PENGGUNAAN METODE ANFIS (ADAPTIVE NEURO FUZZY INFERENCE SYSTEM) PADA APLIKASI PREDIKSI USIA KERTAS
}

\author{
Valeria Cynthia Dewi ${ }^{1}$, Victor Amrizal, Fenty Eka Muzayyana Agustin, ${ }^{3}$ \\ ${ }^{1,2,3}$ Prodi Teknik Informatika, Fakultas Sains dan Teknologi \\ Universitas Islam Negeri Syarif Hidayatullah Jakarta \\ valericynth@gmail.com ${ }^{1}$, fentyema@gmail.com ${ }^{3}$
}

\begin{abstract}
ABSTRAK
Kertas merupakan bahan yang tipis dan rata, yang dihasilkan dengan kompresi serat yang berasal dari pulp. Kertas merupakan salah satu komponen utama dari buku dan dokumen-dokumen. Seiring dengan berkembangnya teknologi saat ini, bukan suatu hal yang tidak mungkin bagi seseorang untuk memalsukan dokumen dan merugikan beberapa pihak contohnya pemalsuan surat wasiat, time sheet records, dan rekam medis. Salah satu cara mengetahui keaslian kertas yaitu dengan mengetahui usia kertas tersebut menggunakan metode Penanggalan Karbon. Tetapi, dengan metode konvensional masih memiliki kelemahan seperti membutuhkan peralatan yang canggih, biaya mahal, proses yang lama, dan askes yang terbatas. Untuk mengetahui usia kertas juga bisa diketahui dengan melihat perubahan warna pada kertas. Untuk memberikan solusi pada permasalahan yang ada, penulis membuat aplikasi yang dapat mengidentifikasi kisaran usia kertas dengan proses yang lebih cepat, biaya lebih murah, dan tidak harus dilakukan oleh pegawai laboratorium. Aplikasi bernama Aplikasi Prediksi Usia Kertas yang dibuat berbasis desktop menggunakan bahasa pemrograman MATLAB. Terdapat dua proses yaitu pembacaan citra dengan Image Processing dengan cara mengambil nilai rata-rata CMYK dari 60 data latih dan proses pencocokan dengan metode ANFIS Sugeno (TSK) fungsi keanggotaan Gaussian. Penelitian didahulukan dengan wawancara, observasi, dan studi literatur. Metode pengembangan aplikasi menggunakan prototype. Hasil pengujian menunjukkan tingkat keberhasilan aplikasi dalam mengidentifikasi 60 data latih sebesar $100 \%$ dan terhadap 40 data yang belum dilatih sebesar $42,5 \%$.
\end{abstract}

Kata Kunci: Usia Kertas, Penanggalan Karbon, ANFIS, Image Processing, CMYK

\section{Pendahuluan}

Kertas merupakan bahan yang tipis dan rata, yang dihasilkan dengan kompresi serat yang berasal dari pulp. Kertas merupakan salah satu komponen utama dari buku dan dokumen-dokumen. Seiring waktu berjalan, usia kertas yang bertambah tua bisa mengakibatkan kertas menjadi rapuh dan mudah hancur. Maka dari itu buku atau dokumen yang usianya sudah tua biasanya disimpan di tempat khusus seperti tempat penyimpanan arsip agar kertas di dalamnya tidak menjadi cepat lapuk.

Dewasa ini, perkembangan teknologi saat ini semakin pesat dan bukan suatu hal yang tidak mungkin bagi seseorang untuk melakukan pemalsuan dokumen demi kepentingannya saja yang berdampak pada banyak pihak. Seperti kasus pemalsuan dokumen yaitu Stenley Mandang, Mth, Pdh, seorang warga Tangerang dilaporkan ke polisi terkait dugaan pemalsuan surat hibah atau wasiat dari Grace Wawuruntu (Arifin, 2013) yang merugikan pewaris. Ada pula kasus seorang anggora polri ditangkap karena memalsukan time sheet records-nya agar memperoleh uang yang lebih banyak dari kantor (wbbjtv.com, 2015) yang mengakibatkan kerugian negara. Begitu pula dengan seorang pekerja di Charlie Norwood VA
Medical Center di Augusta, Cathedral Henderson, tertangkap karena memalsukan rekam medis pasien (rare.us, 2015).

Untuk membuktikan suatu dokumen asli atau tidak, dapat diketahui melalui usia kertas dengan metode Penanggalan Karbon. Berdasarkan wawancara dengan seseorang yang mempelajari ilmu Arkeologi, R. Ahmad Ginanjar Purnawibawa (Konsevator di Kementrian Pendidikan dan Kebudayaan) menyatakan bahwa ada beberapa cara menentukan umur kertas atau naskah. Yaitu dengan interne evidentie dan externe evidentie yang merupakan upaya untuk menentukan umur naskah dari data yang ada di dalam naskah itu sendiri, misalnya angka tahun yang tercatat, peristiwa yang diceritakan, maupun tokoh yang disebutkan. Sementara externe evidentie merupakan upaya menentukan umur naskah dari faktor di luar data yang ada di dalam naskah. Salah satunya dari bahan pembuat kertas. Untuk naskah atau kertas, yang memiliki kandungan organik, dapat digunakan metode pertanggalan carbon dating.

Keuntungan metode penanggalan Radiokarbon, penanggalan Kalium-argon, maupun penanggalan Uranium yaitu dengan melalui proses pengujian laboratorium, perhitungan usia kertas 
dapat menghasilkan keluaran yang tepat, akurat, dan juga dapat mengidentifikasi usia benda yang berasal di waktu yang jauh di masa lampau. Sedangkan, kelemahannya yaitu membutuhkan peralatan terkini dengan biaya yang mahal, memakan waktu yang lama untuk mendapatkan hasil pengujian, dan diperlukan keahlian khusus untuk menggunakan metode ini.

Teknologi pengolahan citra (image processing) bisa digunakan untuk melakukan prediksi keaslian kertas, seperti identifikasi nilai nominal dan keaslian uang kertas rupiah. (Wicaksono, 2007). Pendeteksian nominal uang kertas dan keasliannya dilakukan dengan jaringan syaraf tiruan menggunakan algoritma back propagation. Tujuan penelitian tersebut adalah untuk mengenali nilai nominal uang kertas yang dimasukkan pada mesin penjualan otomatis. Berdasarkan hasil penelitian tersebut dapat disimpulkan bahwa komputer dapat membaca sebuah citra dengan metode image processing untuk mendapatkan identitas dari citra tersebut, maka dari itu komputer dapat juga membaca sebuah citra kertas untuk mendapatkan identitas citra kertas tersebut. Dengan demikian perlu diteliti apakah metode image processing juga dapat digunakan untuk mengetahui umur kertas berdasarkan warnanya.

Dalam penelitian sebelumnya, Nurul Hikmah, Jurusan Teknik Elektro, Universitas Indonesia, pada tahun 2008 melakukan penelitian terhadap ANFIS dan pengolahan citra pada retina mata manusia. Dwi Kris Setianto, Jurusan Teknik Elektro, Universitas Indonesia tahun 2008 juga melakukan penelitian terhadap ANFIS dan pengolahan citra pada iris mata manusia. Dari penelitian di atas didapatkan bahwa metode ANFIS dan Image Processing dapat digunakan untuk mengeluarkan output yaitu berupa solusi dari suatu permasalahan dalam mengidentifikasi citra.

Apabila kita memakai sebuah aplikasi yang dapat memprediksi usia kertas, kita tidak perlu membeli peralatan canggih yang mahal, proses pengerjaan yang dilalui akan lebih sederhana dan lebih cepat, dan semua orang bisa memakai aplikasi ini bukan hanya sebagian orang saja dengan kriteria khusus seperti ahli arkeologi, ahli geofisika, ataupun ahli yang lainnya. Oleh karena itu, pada penelitian ini metode ANFIS dan Image Processing akan diimplementasikan untuk memprediksi usia kertas ke dalam sebuah aplikasi. Aplikasi ini dapat membantu masyarakat ahli maupun biasa dalam melakukan pengecekan usia kertas yang ada pada buku, dokumen penting, maupun kertas yang lain nya.

\subsection{Kertas HVS}

Kertas adalah bahan yang tipis dan rata, yang dihasilkan dengan kompresi serat yang berasal dari pulp. Serat yang digunakan biasanya adalah alami, dan mengandung selulosa dan hemiselulosa.

HVS adalah singkatan dari Houtvrij Schrijfpapier (bahasa Belanda), yang artinya kertas tulis bebas serat kayu. Kertas jenis HVS dibuat dari pulp (bubur kertas) yang tidak mengandung lignin (perekat antar serat di dalam pohon), sehingga tidak mudah berubah warna (menjadi kekuningan) jika diletakkan di bawah sinar matahari atau sinar lampu.

\subsection{Metode Penanggalan Radiokarbon}

Metode penanggalan radiokarbon adalah metode yang digunakan untuk mengetahui usia berbagai benda yang didasarkan pada hasil perhitungan aktivitas karbon-14 yang terkandung dalam benda tersebut atau didasarkan pada perbandingan banyaknya isotop radioaktif karbon14 yang ada pada benda tersebut dengan sebuah sumber standar yang telah diketahui jumlah isotop radioaktifnya. Metode penanggalan radioaktif ini bisa digunakan untuk mengukur umur semua benda selama benda tersebut memiliki karbon-14 di dalamnya, baik benda organik maupun anorganik (Guta dan Polach, 1985 dalam Suci, Anggun, dkk. 2013).

\subsection{Metode ANFIS}

ANFIS (Artificial Neuro Fuzzy Inference System atau Adaptive Network-based Fuzzy Inference System) adalah arsitektur yang secara fungsional sama dengan fuzzy rule base model Sugeno. Arsitektur ANFIS juga sama dengan jaringan syaraf dengan fungsi radial dengan sedikit batasan tertentu. Bisa dikatakan bahwa ANFIS adalah suatu metode yang mana dalam melakukan penyetelan aturan digunakan algoritma pembelajaran terhadap sekumpulan data. Pada ANFIS juga memungkinkan aturan-aturan untuk beradaptasi. (Kusumadewi dan Hartati, 2010) 


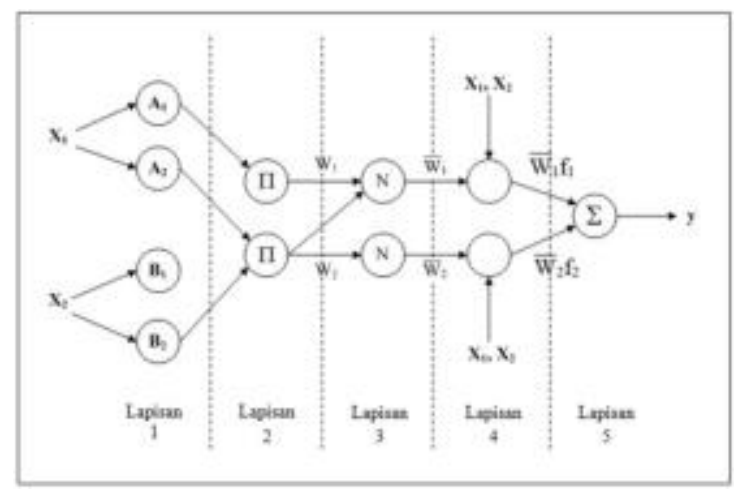

Gambar 1. Arsitektur ANFIS

Jaringan ANFIS terdiri dari lapisan-lapisan sebagai berikut (Kusumadewi dan Hartati, 2010):

a. Lapisan 1: Tiap-tiap neuron i pada lapisan pertama adaptif terhadap parameter suatu fungsi aktivasi. Output dari tiap neuron berupa derajat keanggotaan yang diberikan oleh fungsi keanggotaan input, yaitu: $\alpha_{\mathrm{A} 1}\left(\mathrm{X}_{1}\right), \alpha_{\mathrm{B} 1}\left(\mathrm{X}_{2}\right), \alpha_{\mathrm{A} 2}\left(\mathrm{X}_{1}\right)$, atau $\alpha_{\mathrm{B} 2}\left(\mathrm{X}_{2}\right)$.

b. Lapisan 2: Tiap-tiap neuron pada lapisan ke dua berupa neuron tetap yang outputnya adalah hasil dari masukan. Biasanya digunakan operator AND. Tiap-tiap node merepresentasikan $\alpha$ predikat dari aturan ke-i.

c. Lapisan 3: Tiap-tiap neuron pada lapisan ke tiga berupa node tetap yang merupakan hasil penghitungan rasio dari $\alpha$ predikat (w), dari aturan ke-i terhadap jumlah dari keseluruhan $\alpha$ predikat.

$$
\overline{\mathrm{W}_{\mathrm{i}}}=\frac{\mathrm{W}_{\mathrm{i}}}{\mathrm{W}_{1}+\mathrm{W}_{2}} \text {, dengan } \mathrm{i}=1,2 .
$$

d. Lapisan 4: Tiap-tiap neuron pada lapisan ke empat merupakan node adaptif terhadap suatu output.

$\overline{\mathrm{W}_{\mathrm{i}}} \mathrm{Y}_{\mathrm{i}}=\overline{\mathrm{W}}_{\mathrm{i}}\left(\mathrm{c}_{\mathrm{i} 1} \mathrm{X}_{1}+\mathrm{c}_{\mathrm{i} 2} \mathrm{X}_{2}+\mathrm{c}_{\mathrm{i} 0}\right) ;$ dengan $\mathrm{i}=1,2$.

Dengan $\overline{\mathrm{w}_{\mathrm{i}}}$ adalah normalised firing strength pada lapisan ke tiga dan $\left\{\mathrm{c}_{\mathrm{i} 1}, \mathrm{c}_{\mathrm{i} 2}, \mathrm{c}_{\mathrm{i} 0}\right\}$ adalah parameter-parameter pada neuron tersebut. parameter-parameter pada lapisan tersebut disebut dengan nama consequent parameters.

e. Lapisan 5: Tiap-tiap neuron pada lapisan ke lima adalah node tetap yang merupakan jumlahan dari semua masukan.

\subsection{Model Warna CMYK}

Warna cyan (C), magenta (M), dan yellow (Y) adalah warna komplementer terhadap Red, Green, dan Blue. Dua buah warna komplementer jika dicampur dengan perbandingan yang tepat menghasilkan warna putih. Model warna ini berorientasi hardware, terutama untuk model printer. CMY digunakan hanya untuk mengonversi sistem RGB menjadi sistem yang bisa dilihat oleh mata. Model CMY dapat diperoleh dari model RGB dengan persamaan berikut. (Sutoyo dan Mulyanto, 2009)

Cyan, magenta, dan yellow adalah warna sekunder cahaya, atau merupakan warna primer dari pigmen. Misalnya ketika permukaan dilapisi dengan pigmen cyan diiluminasi dengan cahaya putih, tidak ada cahaya merah yang dipantulkan dari permukaan. Hal tersebut karena cyan mengurangi cahaya merah dari cahaya putih yang dipantulkan, di mana dia terdiri dari perkiraan cahaya red, green, dan blue. (Prasetyo E, 2012)

$$
\begin{gathered}
\mathrm{C}=1-\mathrm{R} \\
\mathrm{M}=1-\mathrm{G} \\
\mathrm{Y}=1-\mathrm{B} \\
\mathrm{K}=\min (\mathrm{C}, \mathrm{M}, \mathrm{Y}) \\
\mathrm{C}=\mathrm{C}-\mathrm{K} \\
\mathrm{M}=\mathrm{M}-\mathrm{K} \\
\mathrm{Y}=\mathrm{Y}-\mathrm{K}
\end{gathered}
$$

\section{METODE PENELITIAN}

\section{A. Metode Pengumpulan Data}

\section{Studi Pustaka}

Penulis melakukan studi pustaka untuk memperoleh informasi serta data-data yang bersumber dari buku, modul, buku elektronik, jurnal, hasil penelitian sejenis, dan website.

\section{Wawancara}

Penulis melakukan wawancara dengan seseorang yang mengerti Arkeologi, Kearsipan, dan Pengamat Benda Kuno. Wawancara ini bertujuan untuk memperoleh informasi mengenai kertas dan cara mengetahui usia kertas menurut pandangan masing-masing narasumber.

\section{Observasi}

Penulis melakukan observasi langsung ke Perpustakaan Utama UIN Jakarta untuk memperoleh data kertas dari buku yang akan digunakan dalam penelitian ini. Data yang diperoleh berupa buku-buku yang terbit dari tahun 1969-2013.

\section{A. Metode Pengembangan Sistem}

Berikut tahapan prototype yang dilakukan:

\section{Pengumpulan Kebutuhan dan Analisis}

Dalam tahapan ini ada tiga hal yang perlu diperhatikan yaitu, analisis masalah, pengkajian dan pembatasan masalah, dan mencari solusi dari permasalahan yang ada.

\section{Perancangan Cepat}


Dalam tahapan perancangan cepat, penulis merancang Data Flow Diagram menggunakan alat Power Designer 6 dan Flowchart menggunakan tools Microsoft Office Visio 2007.Dalam pembuatan Basis Data digunakan tools Notepad. Sedangkan untuk membuat antar muka aplikasi menggunakan tools MATLAB GUI (Graphic User Interface).

\section{Membangun Prototype}

Pada tahap ini dilakukan pengkodean aplikasi yang telah dirancang sebelumnya dalam tahapan perancangan cepat. Pengkodean aplikasi dilakukan menggunakan bahasa pemrograman MATLAB dan dijalankan pada desktop atau laptop.

\section{Evaluasi dan Pengujian}

Pada tahapan ini dilakukan tigas proses yaitu pengujian aplikasi, dokumentasi, dan analisis hasil pengujian. Pengujian aplikasi bertujuan untuk melihat hasil dari aplikasi yang telah dibuat apakah berjalan dengan baik atau tidak.Pengujian yang dilakukan yaitu pengujian secara black box. Pengujian ini dijalankan untuk mengamati apakah program telah berhasil menerima input, memroses, dan menghasilkan output yang sesuai tanpa melihat source code aplikasi.

\section{HASIL DAN PEMBAHASAN}

\subsection{Pengumpulan Kebutuhan dan Analisis}

\section{Analisis Masalah}

Dalam menganalisa masalah, yang pertama kali dilakukan yaitu menentukan parameter apa yang digunakan sebagai masukan sistem. Kedua, observasi yang dilakukan penulis menunjukkan bahwa yang akan digunakan sebagai acuan input yaitu perhitungan yang dilihat dari ekstraksi warna citra. Ketiga, bagaimana dari input nilai citra tersebut dapat diidentifikasi oleh ANFIS yang nantinya dapat menghasilkan output sehingga masalah dalam memprediksi usia kertas terselesaikan.

\section{Pengkajian dan Pembatasan Masalah}

Aplikasi prediksi usia kertas merupakan aplikasi yang dapat memprediksi usia kertas hanya dengan memasukkan input citra hasil scan lembaran kertas. Prediksi usia kertas dapat dilakukan dengan mengambil nilai unik citra RGB yang akan dikonversi ke dalam nilai CMYK yang merupakan identitas setiap citra kertas dan melalui proses matching atau pencocokan terhadap data latih.Database yang digunakan merupakan data latih dari citra hasil scan kertas hvs yang diterbitkan dalam rentang waktu 45 tahun. Yaitu tahun 1969-2014.
3. Mencari Solusi Masalah

\section{a. Mengubah Nilai RGB Menjadi CMYK}

$\mathrm{R}$

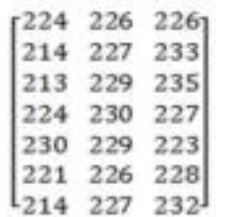

$\mathrm{G}$

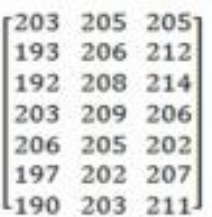

B

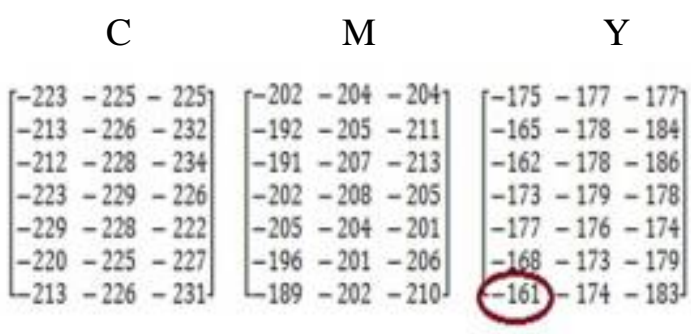

$$
\begin{gathered}
\mathrm{K}=\min (\mathrm{C}, \mathrm{M}, \mathrm{Y})=-161 \\
\mathrm{C}=\mathrm{C}-\mathrm{K} \ldots \\
\mathrm{M}=\mathrm{M}-\mathrm{K} \ldots \\
\mathrm{Y}=\mathrm{Y}-\mathrm{K} \ldots
\end{gathered}
$$

$\mathrm{C}$
$\left[\begin{array}{lll}-62 & -64 & -64 \\ -52 & -65 & -71 \\ -51 & -67 & -73 \\ -62 & -68 & -65 \\ -68 & -67 & -61 \\ -59 & -64 & -66 \\ 52 & -65 & -71\end{array}\right]\left[\begin{array}{lll}-41 & -43 & -43 \\ -31 & -44 & -50 \\ -30 & -46 & -52 \\ -41 & -47 & -44 \\ -44 & -43 & -40 \\ -35 & -40 & -45 \\ -28 & -41 & -49\end{array}\right]\left[\begin{array}{lll}-14 & -16 & -16 \\ -4 & -17 & -23 \\ -1 & -17 & -25 \\ -12 & -18 & -17 \\ -16 & -15 & -13 \\ -7 & -12 & -18 \\ 0 & -13 & -22\end{array}\right]$

Mean $C=\frac{\sum C}{\sum n}=\frac{-1333}{21}=-63,4762$

Mean $\mathrm{M}=\frac{\sum M}{\sum n}=\frac{-877}{21}=-41,7619$

Mean $Y=\frac{\sum Y}{\sum n}=\frac{-296}{21^{\prime}}=-14,0952$

Nilai $\mathrm{K}=-161$

\section{Menentukan Nilai Bobot dan Output dari pelatihan ANFIS}

Untuk pengelompokan bobot dan nilai output, penulis membuat empat kelompok berdasarkan observasi yang penulis lakukan yang terdiri dari empat kategori. Bobot satu artinya tua yaitu tahun (1969-1983), bobot dua artinya sedang yaitu tahun (1984-1998), dan bobot tiga artinya muda yaitu tahun (1999-2013). Satu bobot terakhir yaitu bobot ke-empat merupakan nilai bobot kertas yang warnanya sengaja dituakan melalui proses 
pewarnaan dengan cairan kopi dan teh, bukan perubahan warna yang terjadi karena waktu.

Tabel 4.1 Pemberian Bobot dan Output

\begin{tabular}{|c|c|c|c|}
\hline Output & Keterangan & $\begin{array}{c}\text { Nilai } \\
\text { Minimum }\end{array}$ & $\begin{array}{c}\text { Nilai } \\
\text { Maksimum }\end{array}$ \\
\hline Tua & $1969-1983$ & 0.80 & 1.41 \\
\hline Sedang & $1984-1998$ & 1.56 & 2.19 \\
\hline Muda & $1999-2013$ & 2.93 & 3.04 \\
\hline Buatan & handmade & 3.97 & 4.04 \\
\hline
\end{tabular}

\subsection{Perancangan Cepat}

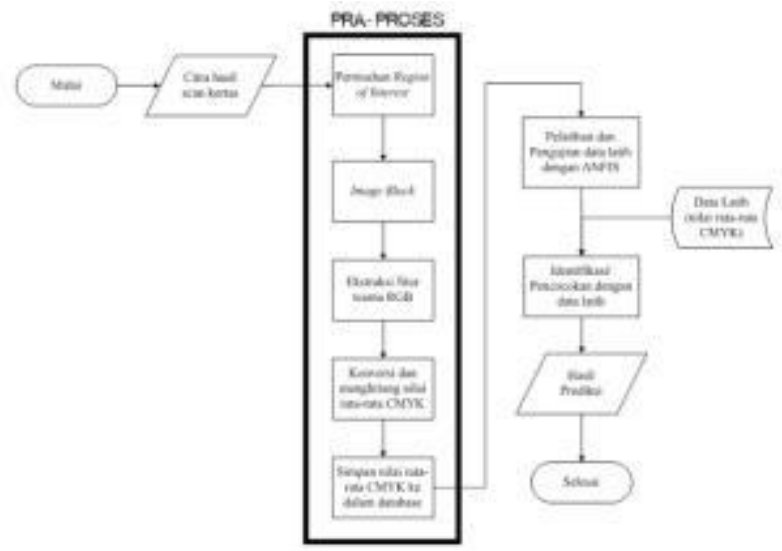

Gambar 2. Flowchart Proses Identifikasi

Tabel 4.2 Data Latih Kategori Tua

\begin{tabular}{|c|c|c|c|c|c|c|}
\hline \multirow{2}{*}{ No } & \multirow{2}{*}{ Kategori } & \multicolumn{4}{|c|}{ Nilai Rata-Rata } & \multirow{2}{*}{ Output } \\
\hline & & $\mathrm{C}$ & $\mathrm{M}$ & $\mathrm{Y}$ & $\mathrm{K}$ & \\
\hline 1 & \multirow{15}{*}{ Tua } & 2,0082 & 1,9483 & 1,8631 & 244,4090 & 1,14 \\
\hline 2 & & 2,0084 & 1,9293 & 1,8274 & 240,4170 & 0,98 \\
\hline 3 & & 2,0081 & 1,9508 & 1,8608 & 246,8220 & 0,93 \\
\hline 4 & & 2,0081 & 1,9692 & 1,9016 & 249,3790 & 1,24 \\
\hline 5 & & 2,0081 & 1,9543 & 1,8654 & 248,1900 & 1,22 \\
\hline 6 & & 2,0081 & 1,9557 & 1,8663 & 248,6220 & 1,12 \\
\hline 7 & & 2,0081 & 1,9670 & 1,8975 & 249,4530 & 1,34 \\
\hline 8 & & 2,0080 & 1,9915 & 1,9590 & 249,4280 & 1 \\
\hline 9 & & 2,0080 & 1,9936 & 1,9589 & 249,6720 & 0,97 \\
\hline 10 & & 2,0080 & 1,9934 & 1,9582 & 249,4210 & 1,18 \\
\hline 11 & & 2,0081 & 1,9862 & 1,9416 & 249,2440 & 0,80 \\
\hline 12 & & 2,0082 & 1,9470 & 1,8602 & 244,6730 & 0,80 \\
\hline 13 & & 2,0082 & 1,9500 & 1,8632 & 246,3040 & 1,20 \\
\hline 14 & & 2,0082 & 1,9491 & 1,8630 & 244,2720 & 1,41 \\
\hline 15 & & 2,0082 & 1,9493 & 1,8649 & 245,8390 & 1,14 \\
\hline
\end{tabular}

Tabel 4.3 Data Latih Kategori Sedang

\begin{tabular}{|c|c|c|c|c|c|c|}
\hline \multirow{2}{*}{ No } & \multirow{2}{*}{ Kategori } & \multicolumn{4}{|c|}{ Nilai Rata-Rata } & \multirow{2}{*}{ Output } \\
\hline & & $\mathrm{C}$ & $\mathrm{M}$ & $\mathrm{Y}$ & $\mathrm{K}$ & \\
\hline 1 & \multirow{15}{*}{ Sedang } & 2,0082 & 1,9643 & 1,8958 & 246,3300 & 1,89 \\
\hline 2 & & 2,0080 & 1,9680 & 1,8980 & 250,2590 & 1,73 \\
\hline 3 & & 2,0081 & 1,9630 & 1,8853 & 248,7020 & 1,92 \\
\hline 4 & & 2,0081 & 1,9573 & 1,8802 & 246,7890 & 2,19 \\
\hline 5 & & 2,0081 & 1,9550 & 1,8735 & 246,9950 & 2 \\
\hline 6 & & 2,0082 & 1,9510 & 1,8633 & 245,0680 & 1,71 \\
\hline 7 & & 2,0080 & 1,9610 & 1,8758 & 250,0610 & 2 \\
\hline 8 & & 2,0081 & 1,9548 & 1,8680 & 247,6650 & 1,66 \\
\hline 9 & & 2,0081 & 1,9613 & 1,8817 & 248,7750 & 1,89 \\
\hline 10 & & 2,0082 & 1,9529 & 1,8726 & 246,5610 & 1,56 \\
\hline 11 & & 2,0083 & 1,9597 & 1,8861 & 242,8930 & 1,99 \\
\hline 12 & & 2,0085 & 1,9441 & 1,8559 & 236,3550 & 1,95 \\
\hline 13 & & 2,0084 & 1,9400 & 1,8487 & 238,5740 & 1,95 \\
\hline 14 & & 2,0085 & 1,9463 & 1,8588 & 237,6020 & 2,09 \\
\hline 15 & & 2,0083 & 1,9542 & 1,8727 & 241,3340 & 1,97 \\
\hline
\end{tabular}

Tabel 4.4 Data Latih Kategori Muda

\begin{tabular}{|c|c|c|c|c|c|c|}
\hline \multirow{2}{*}{ No } & \multirow{2}{*}{ Kategori } & \multicolumn{4}{|c|}{ Nilai Rata-Rata } & \multirow{2}{*}{ Output } \\
\hline & & $\mathrm{C}$ & M & $\mathrm{Y}$ & K & \\
\hline 1 & \multirow{15}{*}{ Muda } & 2,0001 & 2,0064 & 2,0051 & 252,1120 & 3 \\
\hline 2 & & 1,9999 & 2,0039 & 2,0068 & 252,1710 & 3,01 \\
\hline 3 & & 1,9985 & 2,0041 & 2,0061 & 252,2210 & 3,03 \\
\hline 4 & & 2,0004 & 2,0038 & 2,0070 & 251,9910 & 3,01 \\
\hline 5 & & 1,9939 & 2,0008 & 2,0072 & 250,6750 & 2,97 \\
\hline 6 & & 1,9917 & 1,9993 & 2,0076 & 250,1800 & 3,02 \\
\hline 7 & & 1,9946 & 2,0004 & 2,0073 & 251,1040 & 3,02 \\
\hline 8 & & 1,9934 & 2,0002 & 2,0074 & 251,1380 & 2,97 \\
\hline 9 & & 2,0017 & 2,0063 & 2,0061 & 251,7110 & 2,93 \\
\hline 10 & & 2,0027 & 2,0070 & 2,0060 & 251,2190 & 2,96 \\
\hline 11 & & 2,0005 & 2,0067 & 2,0050 & 250,2560 & 3,02 \\
\hline 12 & & 2,0008 & 2,0065 & 2,0051 & 251,3270 & 3,04 \\
\hline 13 & & 1,9835 & 1,9978 & 2,0079 & 250,7320 & 2,99 \\
\hline 14 & & 1,9894 & 2 & 2,0077 & 251,0960 & 3 \\
\hline 15 & & 1,9840 & 1,9981 & 2,0079 & 251,0990 & 3,01 \\
\hline
\end{tabular}


Tabel 4.5 Data Latih Kategori Buatan

\begin{tabular}{|c|c|c|c|c|c|c|}
\hline \multirow{2}{*}{ No } & \multirow{2}{*}{ Kategori } & \multicolumn{4}{|c|}{ Nilai Rata-Rata } & \multirow{2}{*}{ Output } \\
\hline & & $\mathrm{C}$ & M & $\mathrm{Y}$ & K & \\
\hline 1 & \multirow{15}{*}{ Buatan } & 2,0100 & 1,8463 & 1,6796 & 202,3580 & 3,98 \\
\hline 2 & & 2,0091 & 1,8891 & 1,7613 & 220,0820 & 3,99 \\
\hline 3 & & 2,0103 & 1,8350 & 1,6924 & 196,0800 & 4 \\
\hline 4 & & 2,0107 & 1,8231 & 1,6622 & 188,0130 & 4 \\
\hline 5 & & 2,0091 & 1,8805 & 1,7498 & 220,1260 & 4,02 \\
\hline 6 & & 2,0091 & 1,8857 & 1,7638 & 220,0600 & 4,01 \\
\hline 7 & & 2,0088 & 1,8891 & 1,7591 & 228,7500 & 4 \\
\hline 8 & & 2,0087 & 1,8965 & 1,7721 & 231,2380 & 4,01 \\
\hline 9 & & 2,0090 & 1,8900 & 1,7703 & 223,0840 & 3,97 \\
\hline 10 & & 2,0088 & 1,9053 & 1,7988 & 229,4810 & 4,01 \\
\hline 11 & & 2,0090 & 1,8851 & 1,7537 & 222,2500 & 3,99 \\
\hline 12 & & 2,0092 & 1,8789 & 1,7488 & 219,4040 & 4 \\
\hline 13 & & 2,0089 & 1,8992 & 1,7809 & 225,3450 & 4,04 \\
\hline 14 & & 2,0088 & 1,9068 & 1,7971 & 227,6100 & 3,98 \\
\hline 15 & & 2,0097 & 1,8578 & 1,7209 & 208,5751 & 4 \\
\hline
\end{tabular}

\subsection{Membangun Prototype}

\section{Pengkodean Aplikasi}

Pada tahap ini penulis melakukan pengkodean aplikasi menggunakan bahasa pemrograman MATLAB. Proses-proses dalam pengkodean yaitu:

\section{Membangun User Interface}

User Interface dibangun menggunakan MATLAB GUI. Pilihan pada halaman utama yaitu menu, user manual, about, browse, crop image, CMYK, see result, dan Exit.

\section{Pemisahan Region of Interest}

Pemisahan area yang menjadi tolak ukur identifikasi karakteristik citra dilakukan secara otomatis oleh sistem sebesar 100x350 piksel.

\section{Ekstraksi Fitur Warna CMYK}

Pada proses ekstraksi warna didahului dengan mengambil nilai red, green dan blue dari citra asal yang sudah ditentukan Region of Interest nya. Selanjutnya nilai tersebut akan dikonversi menjadi nilai cyan, magenta, yellow, dan black yang dicari nilai rata-ratanya dan nantinya digunakan sebagai parameter input pada ANFIS.

\section{Pelatihan ANFIS}

1. Pelatihan terhadap 60 data latih menggunakan tiga masukan membership function kurva gaussian output linear dengan epoch sebanyak 50, dan metode optimasi hybrid.

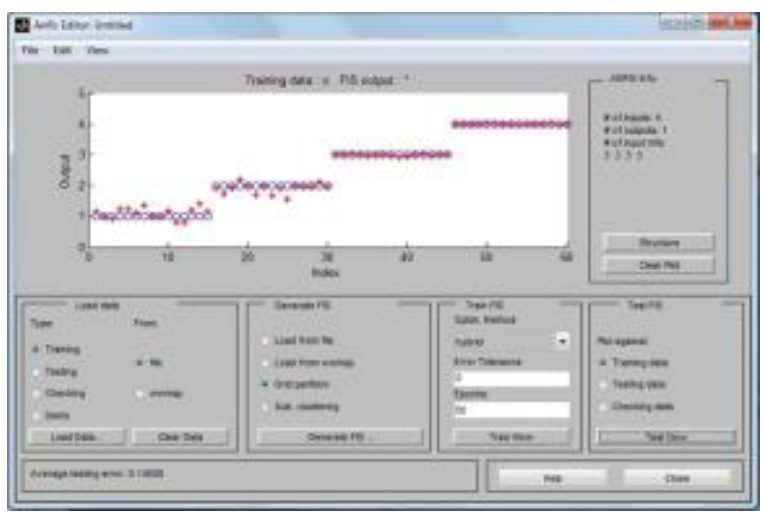

Gambar 2. ANFIS Editor

2. Setelah proses pelatihan selesai, Arsitektur ANFIS yang terbentuk sebagai berikut:

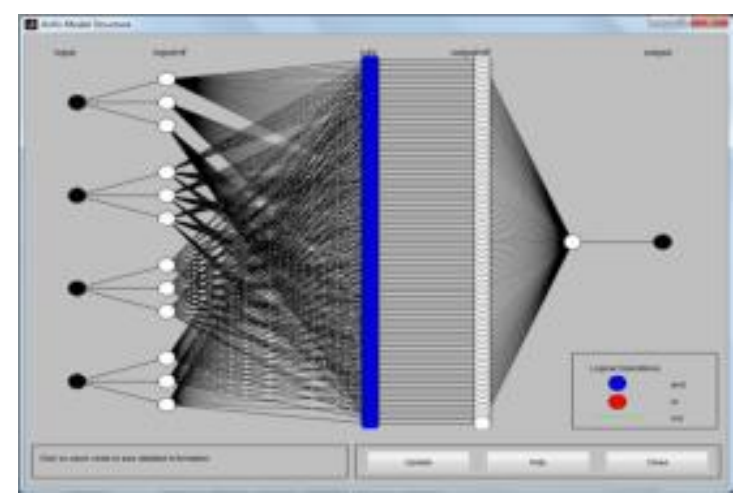

Gambar 3. Arsitekur ANFIS

3. Membership function dan parameter yang terbentuk dari proses pelatihan yaitu:

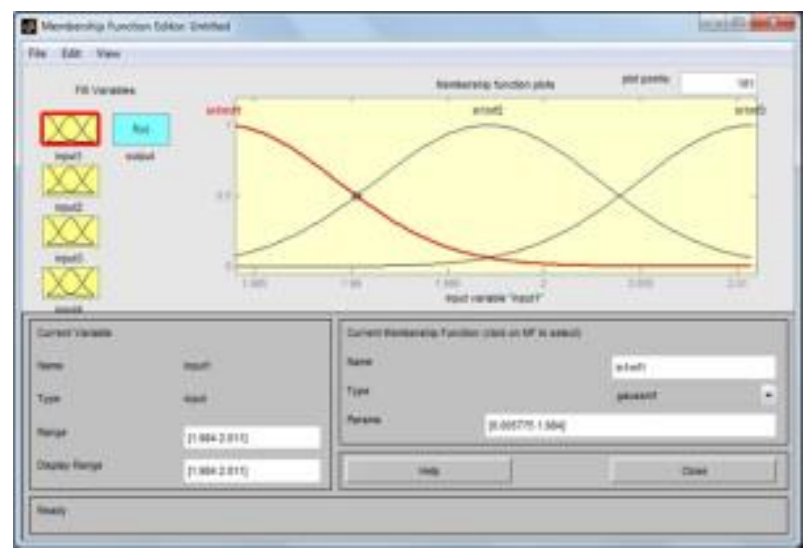

Gambar 4. Membership Function input C 


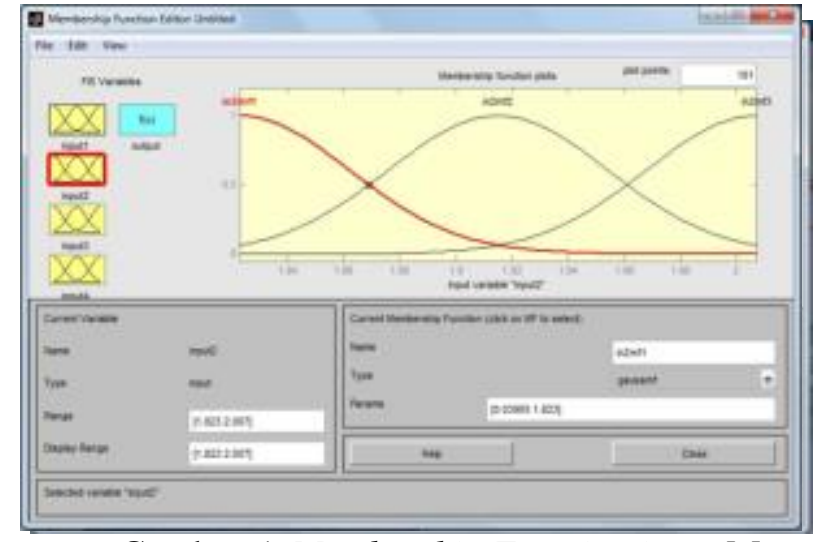

Gambar 5. Membership Function input $\mathrm{M}$

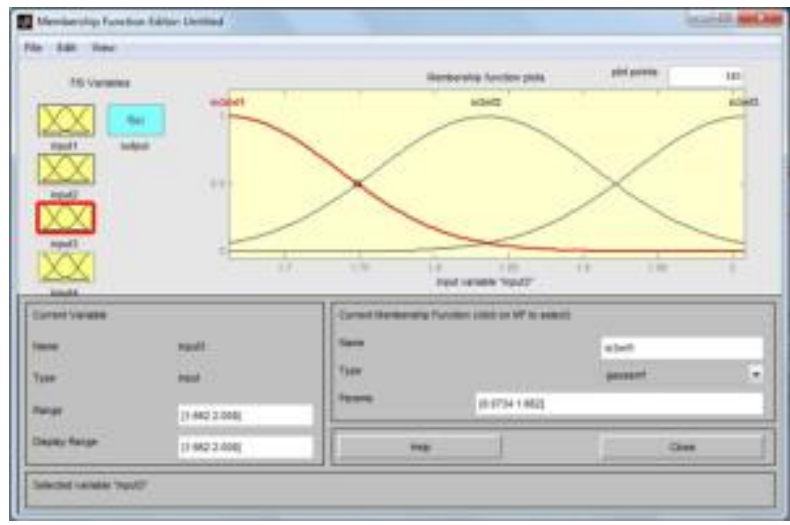

Gambar 6. Membership Function input Y

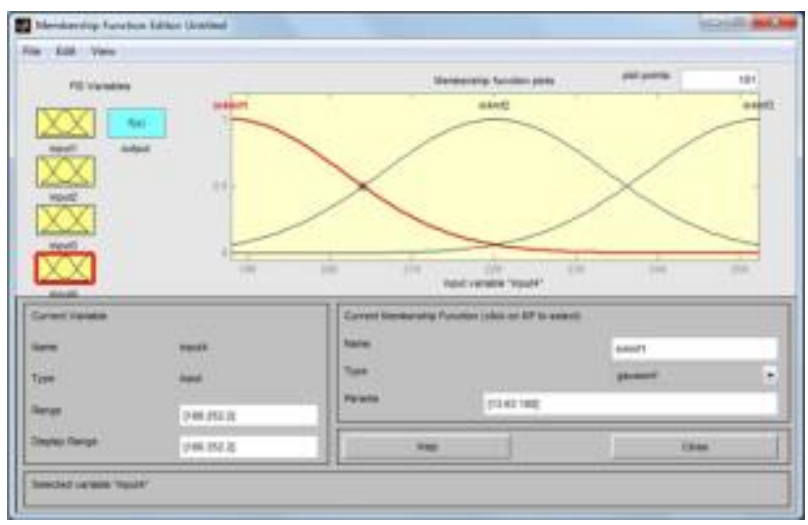

Gambar 7. Membership Function input $\mathrm{K}$

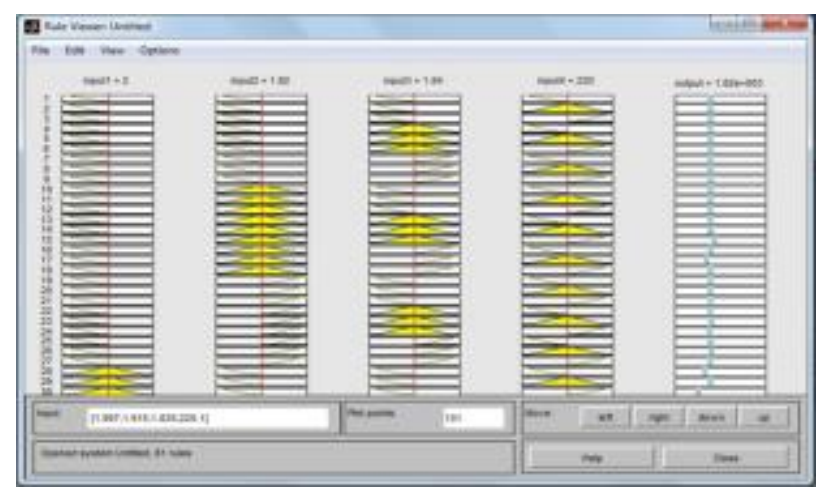

Gambar 8. Aturan yang Terbentuk

\section{Proses Pencocokan}

Setelah data latih melalui proses training dan testing, output dapat diketahui melalui perintah: fis=readfis(' $\left.g 50^{\prime}\right)$ out=evalfis([c m y k],fis);

Lalu membagi output ke dalam empat kategori, yaitu:
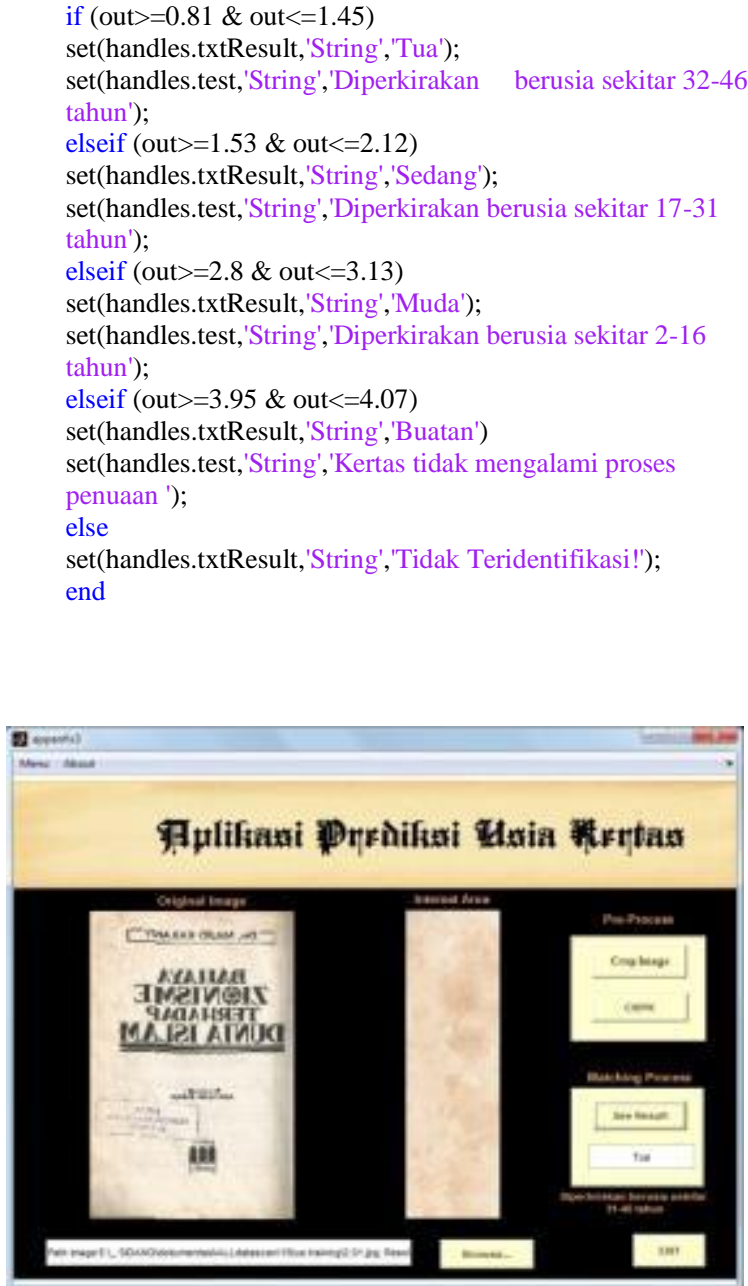

Gambar 9. Hasil Berjalannya Aplikasi

\section{B. Evaluasi dan Pengujian}

Pada pengujian aplikasi prediksi usia kertas menggunakan metode ANFIS dan image processing. Aplikasi dapat mengidentifikasi 77 citra dengan benar dan 23 citra salah teridentifikasi dari total 100 data input. Presentasi keberhasilan keseluruhan sebesar $77 \%$ dengan rincian akurasi pengujian kertas kategori buatan 15\%, kategori muda 19\%, kategori sedang $21 \%$, dan kategori tua sebesar $22 \%$.

Dari 100 data latih yang ditraining, didapatkan seluruh citra teridentifikasi dengan benar. Hal tersebut menunjukkan persentase keberhasilan mengidentifikasi data yang sudah di latih sebesar $100 \%$. Sedangkan, dari 40 data yang belum dilatih atau belum melalui proses training ANFIS terdapat 17 hasil yang benar teridentifikasi dan 23 citra salah 
teridentifikasi. Persentase keberhasilan mengidentifikasi data yang belum dilatih sebesar $42,5 \%$.

\section{PENUTUP}

\subsection{Kesimpulan}

Berdasarkan penelitian yang dilakukan, penulis dapat menyimpulkan bahwa untuk membaca identitas dari setiap citra dapat digunakan pemrosesan citra dengan mengkonversi warna RGB menjadi CMYK.. Untuk memprediksi usia kertas dengan mengkategorikan usia kertas dapat dilakukan menggunakan metode Adaptive Neuro Fuzzy Inference System sebagai alat pencocokan dengan data citra kertas yang telah dilatih.

Dari hasil pengujian terhadap data masukan, aplikasi ini memiliki tingkat keberhasilan keseluruhan sebesar 77\%. Dalam memprediksi usia kertas terhadap data yang sudah dilatih, aplikasi mendapatkan nilai akurasi $100 \%$. Sedangkan pada data yang belum dilatih tingkat akurasi hanya 42,5\%.

Semakin banyak data sample yang dilatih, akurasi hasil identifikasi akan semakin tinggi. Dengan adanya aplikasi ini, usia kertas dengan mudah dapat diprediksi berdasarkan tahun terbit kertas tersebut tanpa harus melakukan uji laboratorium.

\subsection{Saran}

Aplikasi yang dibuat oleh penulis masih memiliki banyak kekurangan sehingga informasi yang dikeluarkan kurang optimal. Untuk itu, diperlukan juga saran-saran untuk dijadikan pertimbangan dalam pengembangan aplikasi, antara lain:

1. Data citra kertas memiliki perbedaan warna pada setiap kategorinya sehingga ketepatan aplikasi dalam memprediksi usia kertas berkurang. Hal tersebut dikarenakan penyimpanan dan perawatan yang berbeda terhadap setiap buku. Akan lebih baik jika kedepannya semua data diperlakukan secara merata misalnya kertas yang disimpan di tempat dan dirawat secara khusus seperti pada ruangan maupun gedung kearsipan.

2. Jumlah Data sample yang lebih banyak akan menambah tingkat keberhasilan aplikasi.

3. Disarankan untuk masa yang akan datang aplikasi ini bisa dikembangkan dan mengidentifikasi usia kertas secara tepat berdasarkan tahun terbit kertas tanpa pengkategorian.

4. Disarankan untuk masa yang akan datang aplikasi ini dapat dikembangkan dengan masukkan jenis kertas yang berbeda-beda.

5. Untuk kertas yang sengaja dituakan harus diklasifikasi lebih detail sesuai dengan kemiripan warnanya apakah termasuk kertas buatan kategori tua, sedang, atau muda sehingga hasil yang dikeluarkan oleh aplikasi akan lebih tepat.
6. Menambah dan memperbesar Region of Interest yang diblok, tidak hanya dari satu sisi saja. Hal ini juga dapat mempengaruhi tingkat keakuratan hasil prediksi

7. Aplikasi dikembangkan dengan bahasa pemrograman lain yang sedang tren seperti Java pada mobile application atau PHP pada web application.

\section{DAFTAR PUSTAKA}

[1] Ahmad, Usman. 2005. Pengolahan Citra Digital \& Teknik Pemrogramannya. Yogyakarta: Graha Ilmu

[1] Anonim. Color Image Processing. http://www. cs.tut.fi/ moncef/SGN-3016-DIP/Chap06.pdf [diakses: 26 April 2015]

[2] Anonim. Sekilas Kertas Leces. Diakses melalui http://www.kertasleces.co.id/index.php pada tanggal 26 Mei 2015.

[3] Anonim. PT Kertas Padalarang. http://www.kertas -padalarang.co.id/id/ [diakses: 26 Mei 2015]

[4] HIGHAM, T. F. G. September 2002. The $C$ Method. Quaternary Geochronology (Quaternary Science Reviews). United Kingdom: Oxford University

[5] Hikmah, Nurul. 2008. Identifikasi Retina Mata Manusia Menggunakan Sistem Inferensi Neuro Fuzzy Adaptif. Skripsi Departemen Teknik Elektro Fakultas Teknik, Universitas Indonesia.

[6] Isna. Kertas HVS Pengertian dan Definisi. http://www.kamusq.com/2012/09/kertas-hvspengertian-dan-definisi.html [diakses: 26 Mei $\underline{2015}$

[7] Kodogiannis, V. S. dan Boulougoura, M. An Adaptive Neurofuzzy Approach for the Diagnosis in Wireless Capsule Endoscopy Imaging. IVPIntracorporeal Videoprobe, European Research Project, Contract no: IST-2001-35169

[8] Kusumadewi, Sri dan Hartati, Sri. 2006. NeuroFuzzy Integrasi Jaringan Fuzzy dan Sistem Saraf. Yogyakarta: Graha Ilmu.

[9] Kusumadewi, Sri dan Hartati, Sri. 2010. NeuroFuzzy Integrasi Sistem Fuzzy dan jaringan Syaraf Edisi 2. Yogyakarta: Graha Ilmu

[10] Kuswadi, Son. 2007. Kendali Cerdas: Teori dan Aplikasi Praktisnya. Yogyakarta.Andi

[11] Ladjamudin, Al Bahra Bin. 2006. Yogyakarta. Rekayasa Perangkat Lunak. Yogyakarta: Graha Ilmu

[12] Ladjamudin, Al Bahra Bin. 2005. Yogyakarta. Analisis dan Desain Sistem Informasi. Yogyakarta: Graha Ilmu

[13] Mirnasari, Nelly dan Adi, Kusworo. 2013. Aplikasi Metode Otsu Untuk Identifikasi Bakteri Tuberkulosis Secara Otomatis. Youngster 
Physics Journal Vol. 01, No. 3, April 2013, Hal 13-20. ISSN: 2302-7371

[14] Pressman, Roger S. Ph.D. 2010. Oftware Engineering, A Practitioner's Approach (Seventh Edition). New York: The McGraw-Hill Companies, Inc.

[15] Suci, Anggun A.S., dkk. 2013. Pembuatan Standar Modern Karbon Gula Pasir Indonesia Untuk Menentukan Umur Fosil Kayu dan Moluska Menggunakan Metode Radiokarbon. Bandung: Prosiding Seminar Nasional Sains dan Teknologi Nuklir PTNBR - BATAN

[16] Swarinata, P. M. 2014. Weather Prediction Application Based on ANFIS (Adaptive Neural Fuzzy Inference System) Method in West Jakarta. Region Jakarta: Fakultas Sains dan Teknologi UIN Syarif Hidayatullah.

[17] Sustantio, Djulianto. 17 Januari 2010. Metode Pertangalan Dalam Arkeologi. http://arkeologipublik.blogspot.com/2010/01/metodepertanggalan-dalam-arkeologi.html. [diakses: 10 April 2015, Pukul: 10.25].

[18] Widodo, P. P. dan Handayanto, R. T. 2012. Penerapan Soft Computing dengan MATLAB. Bandung: Rekayasa Sains.

[19] Wijaya, Marvin Ch. dan Prijono, Agus. 2007. Pengolahan Citra Digital Menggunakan MatLAB Image Processing Toolbox. Bandung: Informatika.

[20] Wicaksono, Dawud Gede. 2007. Perangkat Lunak Identifikasi Nilai Nominal Dan Keaslian Uang Kertas Rupiah Menggunakan Jaringan Syaraf Tiruan Back Propagation, Skripsi, Universitas Indonesia, Tidak Diterbitkan 
